\title{
高分子電解質の対イオン凝繀と電気泳動 \\ Counterion Condensation of Polyelectrolytes and the Electrophoretic Behavior
}

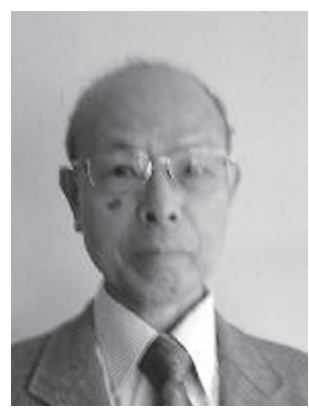

\author{
前田 悠 \\ 九州大学 名誉教授 \\ T 813-0011 \\ 福岡市東区香椎 3-46-6（自宅） \\ Hiroshi MAEDA \\ Professor emeritus, Kyushu University \\ 3 Chome 46-6, Kashii, Higashi-ku, Fukuoka \\ 813-0011, Japan
}

論文要旨：高分子電解質の対イオン凝縮の概念の起源と歴史的な展開を述べるとともに, 凝縮した対イオ ンの微視的状態について, 二, 三の例を紹介した。その際, この概念が棒状形態の高分子イオンに特徵的なも のであることを強調した。添加塩系の相加律についても紹介した。動電現象としては, 高分子電解質の電気 泳動を取り上げ, 素抜け挙動の簡単な解説と, 対イオン凝縮に関係する特徵的な現象として, 対イオンの負 の化学量論的輸率と移動度の飽和効果を解説した。最後に, いろいろな形態のコロイドイオンの場合に, 対 イオン凝縮の概念を拡張することを議論した。まとめとして, 対イオン凝縮の操作的定義を三種類提案した。

\begin{abstract}
The origin and the historical development of the concept of the counterion condensation is described with the emphasis that the concept is inherent to the polyions in rodlike geometry. A couple of experimental results on the microscopic state of the condensed counterions are also discussed. Effects of added salt are discussed in terms of the additivity rule. In the second part, three characteristic aspects of the electrophoretic behavior of polyions are described. (1) The free-draining behavior, (2) Negative stoichiometric transference number of counterions, and (3) The saturation behavior of the mobility with respect to the charge numbers. The last two properties are considered to be due to the counterion condensation. In the final part, arguments are presented regarding the extension of the counterion condensation concept to colloid ions in general, beyond the rod-like geometry. Three operational definitions of the counterion condensation are proposed.
\end{abstract}

Key words: counterion condensation, polyelectrolytes, electrophoresis, negative transference number, the additivity rule

\section{1 はじめに}

線状高分子イオンは, 媒質のイオン強度が低い時は伸 びた形態であるが，イオン強度の増加と共に中性高分子 と同様な丸まった形態となる。イオン強度に依存したこ の形態変化により, 溶液粘度は著しく変化する。他方, 熱力学的性質は, イオン強度によらず棒状（あるいは直 線状）モデルにより理解できることが多い。そして，棒 状形態のイオンに特有な性質を理解するために,「対イ オン凝縮」という言葉と概念が生まれたが, その過程に

連絡者：前田悠

E-mail : maeda@chem.kyushu-univ.jp; maedahrs@cap.bbiq.jp
おいてわが国の研究者は大きな役割を果たした。本稿で は, 第 2 章において, 対イオン凝縮の現象の概略と概念 の歴史的な展開を述べる。第 3 章では, 動電現象として 電気泳動を選び，主に対イオン凝縮に関係した特徵的な 現象を紹介する。高分子電解質の分野の近年の状況につ いては総説を参考にされたい ${ }^{1,2)}$ 。さて, このような史 的背景をもつ対イオン凝縮であるが, 最近の総説 ${ }^{1)}$ か らも伺えるように，この言葉はコロイドイオン一般の場 合に定着しているようである。板状イオンや高分子イオ ンブラシなどでは, 対イオンとの相互作用は棒状の場合 よりも強いから, 対イオン凝縮の概念を棒状に限定する ことは, 確かに不自然である。しかし，コロイドイオン 
の形態によらず，対イオンとの強い相互作用を表現する 言葉として用いるとすると，その定義はどういうもので あろうか。一般的な表現としての「対イオン結合」との 区別はできるのだろうか。このような問題意識から，最 後の第 4 章では, 高分子電解質を離れ, 棒状にとどまら ず一般の形状のコロイドイオンへ，対イオン凝縮の概念 を拡張することを議論する。

\section{2 線状高分子電解質の対イオン凝縮一概念の成立と展開一}

\section{$2 \cdot 1$ 対イオン凝縮の概念の生まれるまで}

対イオン凝縮（counter ion condensation）の概念の 始まりは, 恐らくは, 1938 年の Kern の報告であろう ${ }^{3)}$ 。 ポリアクリル酸ナトリウム（NaPAA）の無添加塩水溶 液の浸透圧係数 (osmotic coefficient) ${ }^{\text {注1) }} \phi$ は, Fig. 1 に 示すように, 0.2 程度の低い值である ${ }^{3)}$ 。浸透圧係数は, 実際の浸透圧 と，その溶液が理想的に振舞うと仮定 した時の浸透圧 $\Pi^{i d}$ の比として定義され $\left(\phi=\Pi / \Pi^{i d}\right)$, 異種符号イオン間のクーロン引力が強いほど小さい值と なる。 $\mathrm{NaCl}, \mathrm{CaCl}_{2}$ などの低分子電解質溶液では, Fig. 1 に示すように $\phi$ は 0.8 以上の場合が多く，上記の 0.2 という值は, 対イオンが高分子イオンの近傍に強く束縛 されていることを示している。希釈により対イオンのエ ントロピーは増加するので, $\phi$ は増大して, 無限希釈に おいて 1 へ収斂する。しかし, Fig. 1 の NaPAAの結果 では, 測定濃度範囲では希釈による $\phi$ の増加は起こらな い。これは高分子電解質の特徵の一つであって, 対イオ ン凝縮の概念により初めて理解できるようになった。こ の不思議な結果を理解する最初の鍵は, 無限長の棒状イ オンの無塩系溶液に対するポアソン - ボルツマン (PB) 方程式の解析解であった。高分子イオンの周りの対イオ ンの分布はPB 方程式により与えられるので, この分布 に基づいて, Lifson-Katchalsky は無限希釈状態の浸透 圧係数を求め, Kern の結果を説明することに成功した ${ }^{4)}$ 。 しかし, この段階では対イオン凝縮の概念はまだ不明確 であった。棒イオンの周りの対イオン分布を，PB式が 与える詳細な連続分布でなく，極めて粗く階段状分布に 置き換える二相モデルを用いて，大澤は対イオン凝縮の

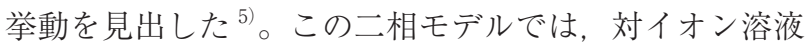
は, 棒に近い領域（内相）とその外の領域（外相）の, 二つの均一濃度領域に分けられる。棒状イオンの線電荷 密度が臨界值を越えると, 内相の対イオン濃度は無限希 棌においてもゼロにならず，有限值に留まる結果が得ら

注 1) Osmotic coefficient に対する正式な訳語は「浸透係数」であ るが, 本稿では「浸透圧係数りを用いる。「浸透」という言葉は, percolation（パーコレーション）にも使用される。浸透圧 係数は溶媒の化学ポテンシャルの尺度であり，浸透圧に限 らず，凝固点降下など，他の束一性（colligative property） を用いても決定できる。

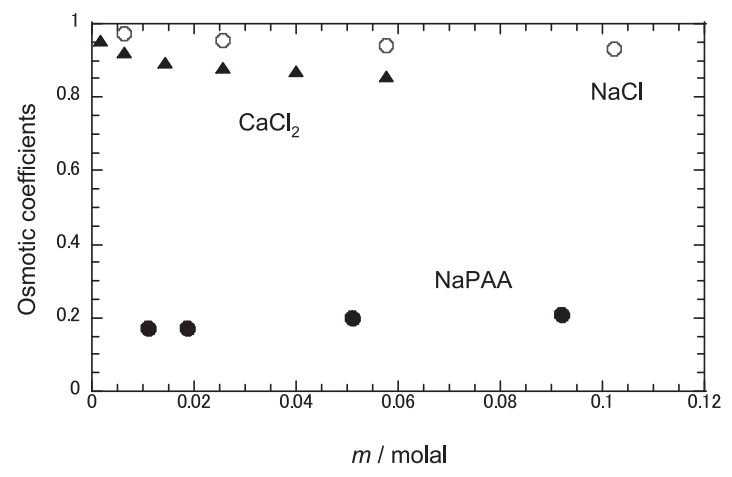

Fig. 1 Osmotic coefficients of aqueous solutions of sodium polyacrylate (NaPAA), $\mathrm{NaCl}$ and $\mathrm{CaCl}_{2}$ at various concentrations $m$. Data for NaPAA are at $20^{\circ} \mathrm{C}$ taken from ref. 3. Data for $\mathrm{NaCl}$ and $\mathrm{CaCl}_{2}$ are at $25^{\circ} \mathrm{C}$ taken from R. A. Robinson and R. H. Stokes, "Electrolyte solutions", 2nd revised Edition, Dover (2002).

れた ${ }^{5)}$ 。この挙動は, 外相の対イオンを気体に, 内相の 対イオンを棒状イオン表面に凝縮した液体に，それぞれ なぞらえることが出来よう。さらに，この特異な結果は 以下の様に説明された ${ }^{6)}$ 。一定量の対イオンを含む溶液 の体積を $\mathrm{V}$ とするとき, 対イオンのエントロピーは一 般に log V の濃度依存性をもつ。他方, 対イオンの電気 エネルギーは, 棒状形態の場合のみ, エントロピーと同 じ $\log \mathrm{V}$ という濃度依存性をもつ。その結果, 希釈 (V の増大）において, 両者の比は一定にとどまり, 稀釈に よる対イオンのエントロピーの優越性が現れない。つま り，内相の対イオン濃度が一定に留まることになる。こ のように，対イオン凝縮は (無添加塩系) 棒状イオンの 無限希釈状態に特有の現象なのである。

\section{$2 \cdot 2$ マニングの極限則}

大澤の二相モデルにより，対イオン凝縮の本質が明ら かになったけれども，対イオン分布を階段状に粗く近似 することの妥当性，内相の半径の意味など，不明な点も 少なくない。Manning（マニング）は, 統計力学的な考 察を進め, 対イオン凝縮の理論的な基礎を確立するとと もに, それに基づき添加塩系も含む一般論を提出した ${ }^{7,8)}$ 。 無限希勫状態の挙動に基礎をおく理論であることから， 極限則 (Limiting Law) と呼ばれている。極限則では線 状高分子イオンは, 電荷の連続分布した線 (line charge）または, 電荷が等間隔で線状に配列した line of charges とモデル化される。また, 線電荷密度パラメー 夕 $\xi$ が中心的な役割を演じる注2)。極限則では，対イオ ンの価数が $z$ の場合, $\xi>1 / z$ では系は希釈とともに不 安定になり，一部の対イオンは線状高分子イオン上に凝 縮して, 実効の $\xi$ の值は $1 / z$ に留まるべきことが示され た ${ }^{7)}$ 。1 価の対イオンの場合, 凝縮した対イオンの数は $(\xi-1)$ に比例し, 凝縮割合 $f_{M}$ は $f_{M}=1-(1 / \xi)$ となる。 
無限希釈の浸透圧係数 $\phi_{0}$ は $\phi_{0}=1 /(2 \xi)(\xi \geq 1)$ および 1 - $(\xi / 2)(\xi \leq 1)$ であり, Lifson-Katchalsky の結果と一致 する。 NaPAA では， $\xi=2.85, \phi_{0}=1 /(2 \xi)=0.18$ である から, Fig. 1 に示す実験結果は理論值と良く一致している。

極限則, 二相モデル，PB 式の三種の方法は熱力学的 性質においては同様な結果を与えている。他方, 凝縮し た対イオンの存在領域については，極限則では棒の表面 近傍に局在することが要請されており（3 章参照），二 相モデルでは内相であり，PB 式の立場では，凝縮割合 $f_{M}$ を与える半径 $R_{M}$ (マニング半径) 以内の領域とする。 なお，実際の高分子イオンは有限の長さであり，測定濃 度も希薄といえども有限である。この問題は総説に詳し く議論されている ${ }^{2)}$ 。

\section{$2 \cdot 3$ 添加塩系と相加律（加成則）}

ここまでは無添加塩系の議論であったが，この節では 共通対イオンを含む塩の添加の効果を考えよう。添加塩 効果については, additivity rule（相加律または加成則） と呼ばれる, 近似的であるが実用的な経験則が知られて いる（Mock-Marshall, 1954）。また，相加律は極限則か らも, PB 式から（Alexandrowicz-Katchalsky, 1963）も, 導くことが出来る。凝縮した対イオンの割合が塩の添加 により殆ど影響されないことが，この経験則の基礎であ ることが理論的に示されている ${ }^{6,7)}$ 。さて, 相加律とは, 高分子イオン $(\mathrm{P})$ と塩 $(\mathrm{S})$ を含む溶液の浸透圧 $\Pi_{P S}$ や対イオン活量 $\alpha_{P S}$ について (1)，(2) 式の関係を指す。 ここに添字 PO と OS は, それぞれ, 無塩系高分子溶液 と純塩溶液を表す。つまり, 無塩系のデータがあれば, 塩添加の効果は, 塩溶液に関する文献デー夕に基づき予 測できるわけである。

$$
\Pi_{P S}=\Pi_{P O}+\Pi_{O S}
$$

$\alpha_{P S}=\alpha_{P O}+\alpha_{O S}$

対イオン活量に関する相加律は，誤差が約 20\%程度 以内で，多くの系で成立している ${ }^{9)}$ 。他方，浸透圧の相 加律については，実験例が少なく，成立している場合と 成立しない場合が共に報告されている。また，イオン性 ゲルの膨潤では, ゲル内外の塩濃度差を与える塩排除因 子が重要である。極限則が与える塩排除因子は実験值よ り小さいが, 高分子濃度が低い場合の極限值としては妥 当である ${ }^{7,10) 。 ~}$

注 2）棒の単位電荷を含む部分の長さを $b$ とするとき, $\xi$ は Bjerrum (ビエルム) 長 $l_{B}$ とbの比として定義される。す なわち, $\xi=l_{B} / b$ 。ビエルム長は, 真空の誘電率 $\varepsilon_{0}$, 比誘電 率 $\varepsilon$, 電荷素量 $e_{0}$, ボルツマン定数 $k$, 絶対温度 $T$ を用いて, $l_{B}=e_{0}^{2} /\left(4 \pi \varepsilon_{0} \varepsilon k T\right)$ と与えられる。本稿では，高分子の解離 基の価数を 1 とする。また対イオンについては，断らない 限り $\mathrm{z}=1$ とする。

\section{$2 \cdot 4$ 凝縮した対イオンの状態}

この節では, 凝縮した対イオンの状態について, 二, 三の実験結果を紹介する。他の例については総説を参照 して頂きたい ${ }^{11,12)}$ 。PAAを $\mathrm{NaOH}$ あるいは $\left(\mathrm{C}_{4} \mathrm{H}_{9}\right)_{4}$ $\mathrm{NOH}$ により中和する時の溶液の屈折率変化は, Fig. 2 に示すように, 中和度 $\alpha$ が 0.4 以下では両者に差はなかっ たが，それ以上では顕著な差が見られた ${ }^{6,13)}$ 。PAAの 場合, $\xi=2.85 \alpha$ であるから, $\alpha>0.4(\xi>1.1)$ の領域で は対イオン凝縮が起こっており, 異なる挙動は凝縮した 対イオンの状態の違いを反映していると考えられる。つ まり, $\mathrm{Na}^{+}$は高分子の近傍に存在して, その水和層を一 部破壊する結果溶液の屈折率は減少するが, 他方, $\left(\mathrm{C}_{4} \mathrm{H}_{9}\right)_{4} \mathrm{~N}^{+}$は水和層の外側に留まると理解できる。超音 波吸収からも同様な結論が得られている ${ }^{11) 。 な お, ~}$ $\left(\mathrm{C}_{4} \mathrm{H}_{9}\right)_{4} \mathrm{~N}^{+}$はサイズの大きいイオンであるが, 浸透圧係 数の挙動から ${ }^{14)}$ 対イオン凝縮が示唆されている。対イ オンが金属イオンの場合, X 線小角異常散乱 (Anomalous small angle X-ray scattering) の方法により，高分子イ オン近傍の対イオンの定量がある程度可能となった ${ }^{12)}$ 。 $\mathrm{Sr}^{2+} \mathrm{PAA}$ の場合には，極限則は $83 \%$ の凝縮割合を予測 するが, X 線小角異常散乱の結果はこの值より遥かに少 ない ${ }^{12)}$ 。これらの例が示すように，対イオン凝縮は本 来熱力学的概念であるから，分子レベルの挙動にはさま ざまなものがあり得ると筆者は考えている。勿論, $\left(\mathrm{C}_{4} \mathrm{H}_{9}\right)_{4} \mathrm{~N}^{+}$のように, 高分子イオン近傍に存在しない場

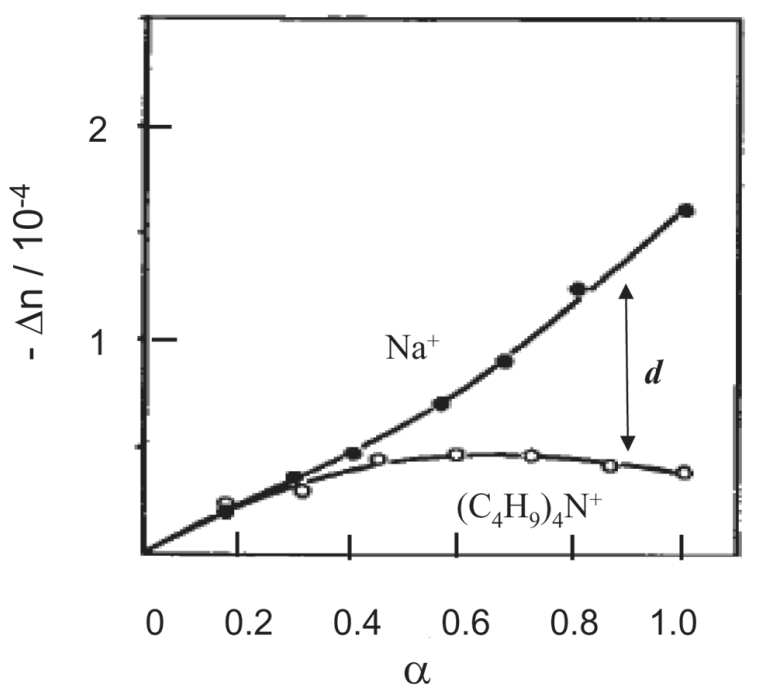

Fig. 2 Refractive index decrements $(-\Delta \mathrm{n})$ at various degrees of neutralization $\alpha$ of poly(acrylic acid). Open and filled symbols refer to the neutralization by $\left(\mathrm{C}_{4} \mathrm{H}_{9}\right)_{4} \mathrm{NOH}$ and $\mathrm{NaOH}$, respectively. Polymer concentration is $50 \mathrm{mN}$. Reproduced from ref. 13. The difference $d$ between the two curves gives the change of the refractive index due to the binding of sodium ions. 
合は, 対イオン凝縮をしていないとする立場もありえる。

実験との比較においては，用いられている高分子イオ ンののの評価の問題がある。マニングは，完全に伸ばし た鎖の中心軸へ投影した電荷間隔の平均值 $b$ から $\xi$ を決 めることを提案している。これは化学構造のみで $\xi$ が決 まる点で優れており, 広く採用されている。しかし, 鎖 の屈曲性が無視できない時は, 電荷間隔は上述の值より 短くなり，対応する $\xi$ は大きくなることが議論されてい る。屈曲性に由来する曖昧さを避ける目的で, 剛直な高 分子イオンを用いた検討もされている ${ }^{15)}$ 。

\section{3 線状高分子イオンの電気泳動}

電気泳動はReuss の発見以来 200 年におよぶ長い歴 史をもち，主としてコロイドや蛋白質の分野において重 要な貢献をしてきている。他方, 線状高分子イオンの電 気泳動は1950年代辺りから活発に研究されるように なった。線状高分子イオン溶液の電気泳動（free solution electrophoresis）には，次の三つの特徵的な挙 動がある。（1）移動度が鎖長に依存しない，（2）対イオ ンの化学量論的輸率が負になる場合がある，（3）電荷量 が多いと移動度が電荷に比例しない飽和効果を示す。

\section{$3 \cdot 1$ 移動度が鎖長（分子量）に依存しない挙動}

コロイドイオンの電気泳動の速度 $U$ は，極めて粗く表 現すれば, 電気的駆動力 $F$ と周りの流体から受ける抵抗 力 $f U$ がつりあうことから, $U=F / f$ と与えられ, 単位電 場当りの $U$ が移動度である。fは鎖全体の摩擦係数であ る。線状高分子では小球（セグメント）が抵抗のない紐 で繋がったビーズモデルが多く採用され，この場合，小 球間の流体力学的相互作用が鎖全体の $f$ を決める。この 相互作用が消えるとき素抜け（free-draining）状態と呼 ばれる。このとき, $\mathrm{N}$ 個のセグメントからなる鎖の $f$ は, セグメントの摩擦係数の $\mathrm{N}$ 倍となり, 電気的駆動力 $\mathrm{F}$ が $\mathrm{N}$ に比例すれば, 両者の比で決まるUは鎖長 (分子量) $\mathrm{N}$ に依存しなくなる。 $\mathrm{NaPAA}^{16)}$ やポリスチレンスルホ ン酸ナトリウム $(\mathrm{NaPSS})^{17)}$ ほか, 多くの系で移動度が 分子量に依存せず, セグメント類似物のものと同程度で あることが見出され，素抜け挙動と理解された。他方， 流体力学的相互作用を考慮した場合でも, 移動度が鎖長

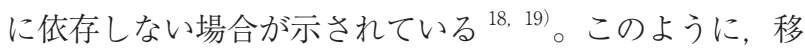
動度が鎖長に依存しないことと素抜け挙動は同一ではな いが，慣例的に前者をも素抜け挙動と呼ぶ場合が多い。 また，高分子イオンを棒とみなして Henry 式を適用す れば, 長い棒の移動度は近似的には長さに依存しない。

\section{$3 \cdot 2$ 対イオンの負の化学量論的輸率}

1950 年にWall らは, 陰極側注3) にのみ放射性 ${ }^{22} \mathrm{Na}$ を トレーサーとして加え, 陽極側注3) には通常の ${ }^{23} \mathrm{Na} し か$
含まないようにして, NaPAA 水溶液（無塩系）に通電

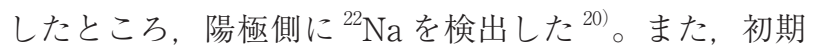
組成を陽極，陰極両側とも同じにした実験では，陽極側 における対イオンの量は中和度 0.6 以上で増加した ${ }^{20)}$ 。 つまり, 中和度 0.6 以上では対イオンの一部はPAA イ オンとともに移動したことになり, $\mathrm{Na}^{+}$イオンの化学量 論的輸率は負になる。これは動的性質における対イオン 凝縮の最初の報告例であろう。

近年, 電気泳動 NMR 法によりこの問題が新たに調べ られるようになった ${ }^{12,21)}$ 。ポリ塩化ジアリルジメチル アンモニウムに二価アニオンのペルフルオロコハク酸

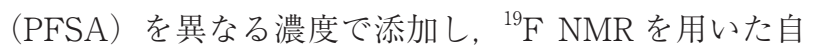
己拡散法により $\mathrm{PFSA}^{2-}$ の位置を追うことにより，移動 度を測定した。対イオンは 2 価なので $\xi>1 / 2$ で凝縮が 起こる。電荷等量点（高分子濃度の半分）まではPFSA の移動度は正であり（陰極に向かう）, 高分子イオンと ともに移動している部分が多いことを示す。電荷量が高 分子の 2 倍（高分子と同濃度）の場合には, 凝縮してい ない対イオンの寄与が勝って, 移動度は小さな負となる (陽極に向かう)。電場下において, 負電荷の対イオンが 正電荷の高分子と共に㓌極に向かって移動することが明 確に示された。

最近, 流体力学的相互作用を考慮したシミュレーショ ンにより， DNA- $\mathrm{NaCl}$ の系で，塩濃度が低い時には対イ オンの一部が DNA と共に移動することが示された ${ }^{22)}$ 。 塩濃度が高くなると, 高分子鎖が溶媒を引きずる効果は かなり遮蔽されて, 対イオンは電場の力に従いDNA と 逆方向（陰極に向かう）に移動する。

\section{$3 \cdot 3$ 高分子イオンの移動度の電荷依存性}

多くの線状高分子イオンでは, 移動度は分子量には依 存しないが, 線電荷密度の増加や媒質のイオン強度の減 少と共に増加すると予想される。しかし, 電荷密度の増 加と共に, 移動度は一定值に収斂する傾向が観測されて いる。0.1 M NaCl 中の NaPAA の場合, 中和度 $\alpha$ の増 加と共に移動度は増加するが， $\alpha>0.6$ では移動度が一 定となった ${ }^{16)}$ 。同様な挙動は, それ以前に高分子イ才 ンの当量電導度の測定からも報告されていた ${ }^{20)} 。$ 完全

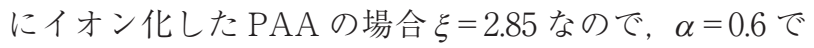
は $\xi=1.7$ 程度になる。また, アクリル酸とアクリルア

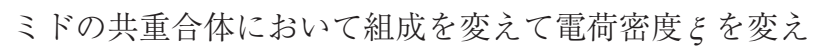
た場合， $\xi>1.5$ で移動度が一定になった (Fig. 3 ${ }^{23)}$ 。移 動度が電荷密度に依存しないで一定となる「飽和現象」 は, 対イオン凝縮と密接に関係していると考えられる。 しかし, 移動度がほぼ一定となる $\xi$ の範囲の下限值 $\xi_{\text {min }}$

注 3）電気泳動や電気分解において, 溶液中の電流は陽極（アノー ド）から陰極（カソード）へ流れる。 
は 1 より大きく，高分子種に依存するようである。 ionene (イオネン) では $\xi_{\min }=1.2$ である ${ }^{24)}$ 。異なる電 荷密度のイオネンの場合, 溶媒の誘電率が異なると, 移 動度は $\xi の$ 值のみで一義的には決まらず, 電荷間隔 $b$ が 短いほど $\xi_{\min }$ は大きくなる ${ }^{24)}$ 。

線状高分子イオンの電気泳動に関する理論は, マニン グのもの ${ }^{18)}$ を除けば PB 式に依拠するものが多く，移 動度は電荷密度とともに増大する。その結果, Fig. 3 に 示した「飽和現象」を導くことは困難である。他方，マ ニング理論では, 凝縮した対イオンが高分子イオンと共 に移動することが要請されており, 移動度は $\xi>1$ で一 定になる。また, 対イオンの化学量論的輸率が負になる ことも自然の帰結である。いずれにせよ，極限則と PB 方程式の二つの方法は, 熱力学的性質においては同様な 結果を与えることを第 2 章で述べたが，電気泳動におけ る対イオン凝縮の効果については際立った違いを見せて いる。

第 3 章で扱った問題は, 高分子イオンの強い電場の束 縛を受けている対イオンに外部電場が作用した時の挙動 とまとめることができよう。この問題は理論的にはまた 解決されていないようである。熱力学概念である対イオ ン凝縮を電気泳動などの動電現象に関係づけることは簡 単ではない。

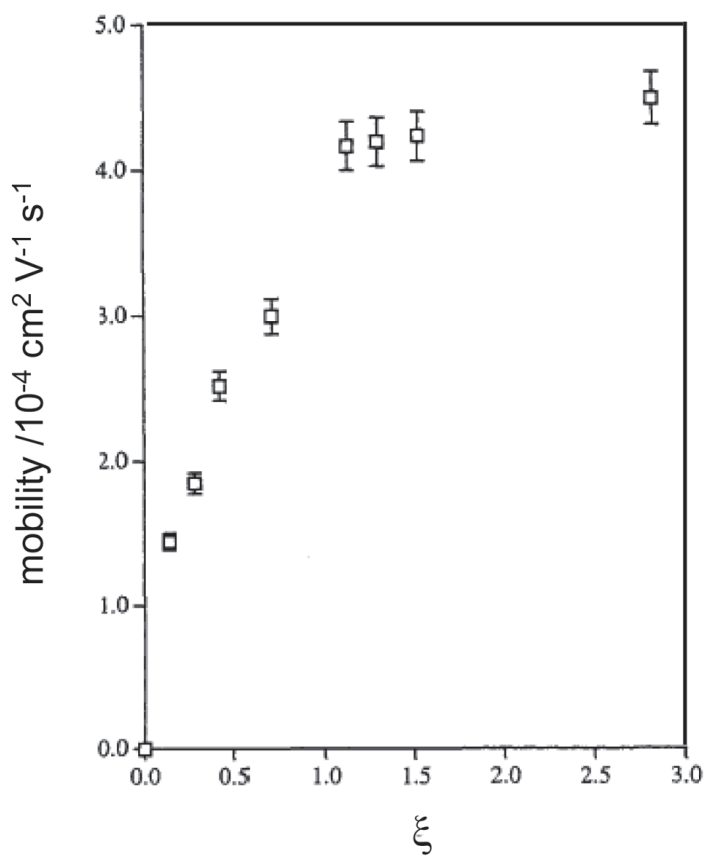

Fig. 3 Free solution electrophoretic mobilities of poly (acrylic acid-co-acrylamide) as a function of the copolymer composition. The composition is expressed in terms of the Manning charge density parameter $\xi$. pH 10.0, 0.03 M phosphate buffer. Reproduced from ref. 23 .

\section{4 棒状以外の形態のコロイドへの対イオン凝縮の概念 の拡張（電荷の繰り込み）}

これまでの章では，高分子電解質について記述してき たが，本学会員の方には，高分子以外にミセル，ベシク ル，エマルションなど，種々のコロイドイオンを扱われ ることが多いであろう。本章ではこれら棒状以外の形態 について, 対イオン凝縮の問題を考える。

\section{$4 \cdot 1$ 電荷の繰り込み（renormalization）}

棒状イオンの場合, 対イオン凝縮の結果, 電荷密度は 元の $\xi$ から $\xi^{*}(=1)$ になるが, これは電荷の繰り込み に相当する。従って, 任意の形状のコロイドイオンに対 して, 電荷 $Q$ が繰り込みにより $Q *$ になった場合は, $(Q$ $\left.-Q^{*}\right)$ を凝縮した対イオン量と考え, これを対イオン 凝縮と呼ぶことが出来よう。この場合, $\phi=Q^{*} / Q$ が良 い近似となる。

球状コロイドの場合には, 無塩系と添加塩系両方に有 効な電荷の繰り込み法として Belloni の方法がある ${ }^{25)}$ 。 $\mathrm{PB}$ 式の数值解に基づき球の周りの対イオン分布を求め ると, 対イオン濃度は球表面近傍で急激に増加するが, その後平坦になり, さらに遠距離で緩やかに増加する場 合が多い。つまり近似的に階段状分布になっている。こ の平坦領域内に位置 Yをとり，それより内側の対イオ ンは凝縮しているとする。つまり, Y は球状イオンに対 する二相モデルの内相の半径に対応するのであるが，そ れが一義的に決まる ${ }^{25)}$

板状コロイドについては，紙面の余裕がないので，成 書 ${ }^{26)}$ を参考していただきたい。

近年, マニングは繰り込み電荷 $Q^{*}$ を決定する一般的 な方法を提案している ${ }^{27)}$ 。Q ${ }^{*}$ をパラメータとした自由 エネルギー $G$ を求め, それを $Q^{*} に$ 関して最小化するこ とにより決定する方法である。しかし, 最小化を効率良 く実行するためには自由エネルギー $G\left(Q^{*}\right)$ が解析的関 数として求まっていることが望ましい。自由エネルギー を静電項 $G^{e l}\left(Q^{*}\right)$ と凝縮仕事 $G^{c o n d}\left(Q^{*}\right)$ の和と近似す る場合, 静電項を線形近似すると, $G^{e l}\left(Q^{*}\right)$ の解析表現 が得られやすく, 最小化の操作が容易になる利点がある。

\section{$4 \cdot 2$ 球状ブラシ}

電荷繰り込みの方法の具体例として，複雑な形状のコ ロイドイオンであるイオン性球状高分子ブラシ (SPB) の無添加塩溶液の場合を紹介する。固体基板に高分子を 沢山固定したものを高分子ブラシと呼ぶ。同一ポリスチ レンラッテクス (半径 $68 \mathrm{~nm}$ ) に異なる鎖長の NaPSS の 鎖（全長が 86-165 nm）をもつ三種の SPB の場合, 浸 透圧係数は濃度に依存せず $0.02-0.06$ の值が報告されて いる ${ }^{28)}$ 。ビニル系高分子電解質の場合 $(\sim 0.2)$ と比較す 
れば一桁小さく，きわめて強い対イオン凝縮といえる。 他方, 浸透圧係数の理論的評価には, ブラシ域と外層の 対イオン濃度の見積りが必要である。Jusufi らは, 外層で は電荷密度（対イオン濃度に等しい）は一定, ブラシ域 では電荷密度は $1 / r^{2}$ に依存すると仮定した。この粗いモ デルに基づき自由エネルギーを求め，その最小化により 外層の対イオン濃度を決める。それから浸透圧係数を計 算すると $0.003-0.004$ となった ${ }^{29)}$ 。興味深いことに，大 澤の二相モデルにおいてブラシ層を内相とすると，極め て簡単な計算によりほぼ同じ值が得られる。いずれにせ よ，計算值は実測值より一桁ほど浸透圧係数を過小評価 している。複雑な形態になるほど, 自由エネルギーの解 析的表現を得るためには，粗い近似が必要となり，電荷 の繰り込み操作を精度良く行うことが容易でなくなる。

\section{5 おわりに}

「はじめに」において述べたように，「対イオン凝縮」 の用語は棒状イオンに限定すべきという立場もあろう。 逆に，特に定義しないで，コロイドイオン一般に対して 使用する立場もあろう。後者の場合の「対イオン凝縮」 は「対イオン結合」とほとんど同義になろう。本稿では, どちらとも異なるひとつの立場を提案してみたい。一般 的な言葉としての「対イオン結合」と区別して, 特に「対 イオン凝縮」と呼ぶためには, 実験結果に依存した操作 的定義（operational definition）が必要であろう。それ には本稿の内容に即して, 無塩系溶液について, 次の三 種が考えられる。（1）希薄濃度における浸透圧係数が 1 以下の有限值に留まること（第 2 章），(2) 対イオンの 化学量論的輸率が負であること（第 3 章），（3）電荷の 繰り込みの処方箋が存在すること (第 4 章)。これらの いずれか一つが確認できれば，その現象を対イオン凝縮 と呼ぶことを提案したい。これらの定義は異なる内容を もつので，互いに異なる判定を与える場合がある。例え

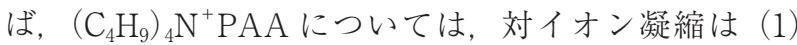
の定義では起こっているが，(2) の定義では起こってい ない可能性が高い。

本稿では荷電コロイドの対イオン凝縮について, 線状 高分子イオンを中心にその概念を概観した。対象は無塩 系の孤立したコロイド粒子に，理論面では平均場近似の 範囲の話に限定した。紙数の関係で，対イオン凝縮の実 験例, シミュレーションの成果, コロイドイオン間相互 作用における対イオン凝縮の効果など，重要かつ興味深 い話題を省かざるを得なかったことをお詫びする。

\section{謝 辞}

本稿の執筆に際し，多くの助言を下さった高木俊夫博
士（大阪大学名誉教授）にお礼を申し上げます。

\section{参考文献}

1) Curr. Opin. Colloid Interface Sci., 13 (2008): 17,(2012) に polyelectrolytes の特集がある。

2) Dobrynin AV, Rubinstein M., Prog. Polym. Sci., 30, 1049-1118 (2005).

3) Kern W, Z. physik. Chem. A181, 249-282 (1938).

4) Lifson S, Katchalsky A, J. Polym,. Sci., 13, 43-55 (1954).

5) Oosawa F, J. Polym,. Sci., 23, 421-430 (1957).

6) Oosawa F, "Polyelectrolytes", Marcel Dekker (1971).

7) Manning GS, J. Chem. Phys., 51, 924-933 (1969).

8) Manning GS, J. Chem. Phys., 51, 934-938: 3249-3252 (1969)

9) Lyons JW, Kotin L, J. Amer. Chem. Soc., 87, 1670-1678 (1965).

10) Kakehashi R, Maeda H, J. Chem. Soc. Faraday Trans., 92, 3117-3121: 4441-4444 (1996).

11) Manning GS, Ber. Bunsenges. Phys. Chem., 100, 909922 (1996)

12) Huber K, Scheler U, Curr. Opin. Colloid Interface Sci., 17, 64-73 (2012).

13) Ikegami $A$, J. Polym,. Sci., A2, 907-921 (1964).

14) Chu P, Marinsky JA, J. Phys. Chem., 71, 4352-4359 (1967).

15) Blaul J, Wittemann M, Ballauff M, Rehahn M, J. Phys. Chem., B114, 7077-7081 (2000).

16) Noda I, Nagasawa M, Ota M, J. Amer. Chem. Soc., 86, 5075-5079 (1964)

17) Nagasawa M, Noda I, Takahashi T, Shimamoto N, J. Phys. Chem., 76, 2286-2294 (1972).

18) Manning GS, J. Phys. Chem., 85, 1506-1515 (1981)

19) Shendruk TN, Hickey OA, Slater GW, Harden JL, Curr. Opin. Colloid Interface Sci., 17, 74-82 (2012).

20) Huizenga JR, Grieger PF, Wall FT, J. Amer. Chem. Soc., 72, 2636-2642 (1950).

21) Böhme U, Scheler U, Macromol. Symp., 211 87-92 (2004).

22) Fischer S, Naji A, Netz RR, Phys. Rev. Lett., 101, 176103 (2008)

23) Hoagland DA, Smisek DL, Chen DY, Electrophoresis, 17, 1151-1160 (1996)

24) Popov A, Hoagland DA, J. Polym,. Sci. B, 42, 36163627 (2004)

25) Belloni L, Colloids Surfaces A, 140, 227-243 (1998).

26) Evans DF, Wennerström H, "The Colloidal Domain", Chapter 5, VCH (1994).

27) Manning GS, Macromolecules, 40, 8071-8081 (2007): J. Phys. Chem., B111, 8554-8559 (2007).

28) Das B, Guo X, Ballauff M, Prog. Colloid Polym. Sci., 121, 34-38 (2002).

29) Jusufi A, Likos CN, Ballauff M, Colloid Polym. Sci., 282, 910-917 (2004). 